\title{
Accounting Procedures within a Decentralised Zimbabwean Financial Management School System
}

\section{V.C. Ngwenya ${ }^{1} \nless$ J. Maushe ${ }^{2}$}

'Department of Arts and Education Zimbabwe, Open University, Bulawayo Region, Bulawayo, Zimbabwe ${ }^{2}$ Waterford Primary School, Dold Avenue, Bulawayo, Zimbabwe

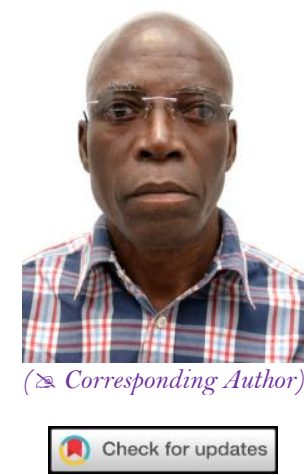

\begin{abstract}
The study sought to examine the effective utilisation of accounting procedures by accounting officers in Zimbabwean public schools within a decentralised financial management system in order to minimise the mismanagement of public funds. A qualitative approach of an interpretive nature was employed consisting of a semi-structured interview, observation and document analysis in the collection of data. Forty participants were selected using a purposeful nonprobability sampling technique. Some qualitative data collected was converted to quantitative data for analysis purposes. Results revealed that the generality of Zimbabwean public schools employ appropriate accounting procedures although the 'Banking Register', 'Payment Vouchers' and 'Procurement Minute Book', 'reconciliation statements' and 'end of year returns' were found wanting. Consequently, fraudulent activities and misappropriation of public funds seem to be rampant in schools. Researchers recommend that accounting officers be work-shopped, finance duties be delegated within the committee framework, both internal and external controls be intensified to curb the rot.
\end{abstract}

Keywords: Accounting, Delegation, Financial management, Misappropriation, Qualitative data.

\section{Introduction}

The Ministry of Primary and Secondary Education (MOPSE) has it on record that it has been flooded with allegations of funds being embezzled or mismanaged by education managers, a cancer they want to uproot by having a school finance policy which would facilitate the employment of accountants for either one school or many depending on the availability of funds (Ncube, 2016). Such a thrust would enable education managers concentrate on their core business of the educative enterprise and minimise the mismanagement of public funds in schools. By the same token, accounting procedures are very critical in a school system, for they help the education manager as the Chief Accounting Officer (CAO) to make informed decisions and minimise errors in handling financial transactions. The procedures, if followed or monitored properly can provide relevant information to aid the education manager in financial planning, decision-making and control (Matimbe, 2014). The financial data collected through procuring school materials, payment vouchers (PVS) and receipts, banking and reconciliation and the financial accounts can help the education manager to monitor the financial trends and improve one's internal controls in order to reduce financial risks in the school (Matimbe, 2014). In that light, the existence of some education managers who fail to account for revenue in terms of cost risks and control due to lack of financial knowhow in the wake of the decentralisation of financial management in the education arena, is a cause of concern. It is therefore, within that context that the study seeks to investigate the accounting procedures The Public Finance Management Act SR (2011) which may be employed by education managers as they manage public funds in their schools within a revolutionised financial management system.

\subsection{Background to the Study}

Nowadays cases of misappropriation of public funds in both public and private schools are rampant in the Zimbabwean education system (Harare Bureau, 2016). In the past, Treasury through the Ministry of Finance used to control the collection and disbursement of school fees through its Consolidation Revenue Fund SR (2011). Learners in government schools paid their fees at the Post Office and brought receipts to schools as evidence of payment. This money ended up in the Finance Ministry's Consolidation Revenue Fund. Schools were allocated money in the form of figures which they utilised via the Regional offices. In that view, schools did not handle public funds as this was the responsibility of the responsible authority, all they were allocated were figures which they would confirm with the Accounting officers at their Regional Offices, now referred to as Provincial Education 
Director's (PED) Offices. Of late, the government intending to make schools more transparent and accountable to their stakeholders, financial management has been decentralised to school level. This kind of empowerment has made schools handle large sums of money. Although the empowerment has its own merits, it has made either education managers or bursars or School Development Association (SDA) (Statutory Instrument [SI] 379 of 1998) members vulnerable to the crime of embezzlement of public funds either by design or default (Harare Bureau, 2016). Schools through the decentralised financial management system advocated for by government are custodians of tuition fees, levies, equalisation grants, building grants, per capita grants, fundraising funds and donations to some extent (SI, 379 of 1998). Many a time when auditors visit schools for financial management inspection, most schools have been found with skeletons in their cupboards (Ncube, 2016). Their failure to adequately account for the public funds under their custody has been due to their failure to religiously adhere to the proper financial accounting procedures as stipulated by government statutes SR (2011). Millions of dollars have been lost this way with the recent national audit revealing that many private schools have been prejudiced of 1.2 billion dollars due to shoddy deals by those responsible for handling public funds (Harare Bureau, 2016). Such audits have revealed that education managers in most cases flout accounting procedures either by design or default which ends up making them vulnerable to fraudulent activities or flouting tender or procurement procedures due to ill-financial management practices (Matimbe, 2014). This rot has led many education managers to lose employment, a trauma and dent they live with for the rest of their life. Cases of some culprits committing suicide are no longer uncommon (Ncube, 2016) hence this study which is meant to equip education managers with the appropriate software for financial management practices at school level.

To make matters worse, the bulk of education managers who have been dismissed by the Civil Service Commission have been found to lack financial management skills to employ internal accounting controls within their institutions (Matimbe, 2014). Lack of financial methods or strategies to account for revenue properly in terms of cost, risk and control usually leads to poor decisions and planning towards goal achievement. Although the MoPSE, has put in place statutes and regulations which can help in curbing these fraudulent activities (School Regulations [SR], 2011) if adhered to precisely. However, the majority of education managers have been caught on the wrong side of the law either intentionally or unintentionally, hence, this study.

\subsection{Legalised Revenue Accounting Procedures for Schools}

\subsubsection{Procurement Procedures}

The SR (2011) clearly stipulates that public schools must have a procurement committee that authenticates and recommends all purchases at that particular institution. The committee comprises three teachers and a representative of the parent body and attempts should be made to represent the various sections/departments of the school (Matimbe, 2014). The committee is mandated by the statute to generate three quotations on the cost of goods, services and materials the school intends to purchase. Thereafter, they deliberate on the quotations by way of analysis and compile a comparative schedule. This effort should lead to the selection of the best supplier based on merit not the cost accompanied with a written justification focusing on price range, quality and quantity (Chigwamba, 2013). The results of such a process are forwarded to the School Finance-Sub Committee [SFSC] (SI, 379 of 1998) for further scrutiny and release of funds (Matimbe, 2014). However, members of the procurement committee need to be acquainted with the reputable suppliers they are supposed to purchase from as a way of policy so as to guard against conflicts of interests. It is in this manner that, Masasi (1997) believes that procurement is a structured procedure designed to consult the market for the purchase of these goods and services. This process if conducted in a transparent and accountable manner, informed financial decisions would be made in the attempt to procure quality services and goods for the function of the school.

Furthermore, the devolution of power through delegation of duties strengthens the operations of the school system (Masasi, 1997). All things being equal, the procurement committee should work within the confines of the School Development Plan (SDP) in consonance with the SFSC which comprises the education manager, deputy head, SDA chairperson and vice chairperson to minimise risks of financial management and promote quality services. Other teachers may be roped in as members of the SFSC depending upon the needs of the school at the discretion of the education manager provided such a development has been communicated to the Permanent Secretary for Education for concurrence (SI, 379 of 1998). The operations of the procurement committee are further strengthened by the clause that spells out that at no time should procurement be done without an official requisition or purchase order SR (2011) thus reducing the risk of corrupt practices which may be caused by noncompliance of this statute.

\subsubsection{Payment Vouchers (PVS) and Receipts}

Matimbe (2014) stresses that all payment into and out of the school account must be recorded as part of the accounting procedures recommended by the financial statutes. Expenditure as payment of cash or cash equivalent for goods and services should be evidenced by an invoice, receipt, voucher or other relevant documents (Chigwamba, 2013). Preparation of PVS is one of the payment procedures which should be used in schools. After receiving a supplier's invoice, one must create a voucher before issuing payment. The SFSC approves the payment and the recommended authorising signatories authorise the payment (SI, 379 of 1998). The PVS are written for payments made by the school. This view is corroborated by Bansal (2011) who asserts that PVS must be prepared for all payments made by the school. Proper documents such as the quotation, invoice, order forms and comparative schedules must be attached to the voucher as proof of all the procedures which would have been followed in the process of purchasing goods or services. The PVS should show what the payment was made for and informs both the school and stakeholders what the funds in the school account have been used for. Proper PVS should be crafted according to specifications comprising serial numbers, payee and address in full, amount, details of payment and supported by the SFSC meeting number [1\2015] SR (2011). This latter document further advocates that public institutions make payments using cheques, unless purchasing small items that is when petty 
cash may be used. All the procedures followed on payment vouchers can be used to account for revenue in the school, thus, helping the education manager in making informed financial decisions.

On the other hand, receipts are for payments made into the school or as an acknowledgement of the payment received by the supplier (Matimbe, 2014). Chigwamba (2013) is also in league with this view when he postulates that a receipt plays a very crucial role in the revenue accounting and should be issued to a pupil after payment of tuition fees or levies has been made as a way of confirmation of such a transaction. The SR (2011)suggest that the school should issue a receipt for all monies received and a counterfoil and a duplicate of the receipt should contain all information about the amount received. Erasers should be avoided at all cost, however, where they have been done, such receipts should be cancelled and should not be detached from the receipt book (SR, 2011). Similarly, Bansal (2011) further asserts that a receipt should have all the necessary details of the person who has done the payment. For example, in a school system, it should include the name of the learner as it appears in the attendance register, date of issue, amount received in figures and in words, the item for which the payment was made and the signature of the receipting officer (SR, 2011). The Accounting Procedures Manuals [APM] (1984) equally supports the alluded to procedure by stating that the payer's details and the receipting officer's signature should be endorsed on the receipt.

PVS and receipts are accounting procedures which indicate transparency on expenditure and revenue collected in the school respectively. The procedures help the education manager to avoid risks in accounting for revenue in the school.

\subsubsection{Banking and Reconciliation}

These procedures can be used to account for revenue by the education manager. The Treasury Instructions [TI], (1992) makes it mandatory for every school to open a bank account so that all the revenue collected will be kept safely. The same procedures are corroborated and further elaborated in the SR (2011). Both statutes prescribe that an education manager must ensure that all funds received are banked intact into the account to reduce misappropriation. Hill (2015) in collaboration with the above sentiment asserts that banking receipted money intact reduces the risk of loss through theft and other mishaps. This means that after daily receipting, all the total payments should be summarised and mastered in the master receipt book. Physical and total collected funds should be balanced. Then that amount should be entered in a deposit slip or deposit book in duplicate so that when the bank takes the original receipt the duplicate remains. The amount should also be posted in the banking register which should bear the signature of the deputy education manager or any designated teacher. The depositor should bring back the stamped duplicate deposit slip for filing and auditing purposes (TI, 1992). Finally, all the banking transactions must be reflected in the cash book (Masasi, 1997) in fact, every receipt, even the cancelled one should be accounted for in the cash book.

It is the cash book which will be used for reconciliation procedures together with the bank statement at the end of each month. Kent (2015) confirms that the process of preparing a reconciliation statement involves making adjustments to the balances on the bank statement and the cash book so that the figures tally. It is in this case, whereby every item should be accounted for. Reconciliation is a tedious job and needs someone who does the calculations correctly and meticulously (Hill, 2015). Mathematical errors entered in the cash book makes it difficult to reconcile such accounts. For instance, if one writes $\$ 4,21$ as $\$ 4,12$, one would have sleepless nights trying to reconcile such figures. At a glance of the reconciliation statement, the education manager is able to ascertain the financial position of the school and be capable of making informed financial decisions during the budgeting process as SDP are developed. The reconciliation of revenue and expenditure in relation to what has been banked enables education managers to detect errors as they occur (Hill). This daunting task demands that education managers counter-check and certify the reconciliation by signing as a way of an internal control system in the institution (Hill).

\subsubsection{Financial Accounts}

These are end of year returns which should be prepared by the education manager and the SDA so that they report the financial statement to their stakeholders (TI, 1992; SI, 379 of 1998). The reporting of finances should be done by the SFSC each year. In addition, the education manager should see to it that the bursar does quarterly financial accounts where details such as the receipts and payments, cash flow statement and balance sheets which are then sent to the accounting officer stationed at the PED's office for auditing purposes (Matimbe, 2014). If education managers follow the end of year procedures, they will make informed decisions and distribute school finances efficiently because the statement presents an analysis of the use of the organisation's resources and flow of goods, money and services to, within and from the organisation (Szilagyi, 1981).

\subsection{Problems Associated with Non-Compliance of Accounting Procedures}

Accounting procedures discussed prior are very critical in financial management. They are in actual fact the internal control measures school systems may utilise (Bansal, 2011). The procurement process involves a lot of individuals through devolution of power. Segregation of duties reduces errors and risks in the accounting process. Porter and Norton (2004) believe that without segregation of duties, an employee is able to perpetrate a fraud and conceal it. An education manager in a school, who does not have a procurement committee in place, ends up flouting procurement and tender procedures. In most cases such education managers usually corrupt the procurement procedures by engaging their own relatives or friends instead of engaging authorised book suppliers or shops (TI, 1992). In the process they temper around with the figures with the intention of converting the difference to their personal use, a practice which sent many Zimbabwean school authorities to prison (Ncube, 2016).

In addition, PVS are also meant to be internal controls on expenditure (Bansal, 2011). Authorisation of payment which is done after PVS preparation is a cover up for any mischief by the education manager (TI, 1992). The involvement of the SFSC also reduces the misappropriation of school funds (SI, 379 of 1998). In addition to these checks and balances, Oakland (2000) suggests that regularised audits be augmented by private ones to ensure 
compliance of proper accounting procedures. This therefore, calls for strict adherence to financial statutes by accounting officers in the school system to ensure correct collection and disbursement of such funds. In fact, if the money is directed to issues which do not benefit the pupils, the CAO is accountable. In that light, proper authorisation, segregation of duties and individual verification of PVS is crucial to proper financial management (Masasi, 1997; Bansal, 2011).

Receipting procedures on both payments and expenditure can protect the $\mathrm{CAO}$ from the temptation of misappropriating public funds if they are followed religiously (SR, 2011). Cancellation which is prohibited at all costs on receipts reduces forgery $(\mathrm{SR}, 2011)$. If procedures on receipting are not followed, some members of the SFSC may loot funds by generating invoices with inflated prices of goods and learning materials they purport to have bought (Chiri, 2015). It is therefore, to the SFSC's advantage to use PVS and receipts for their intended purposes if revenue is to be realized in the school.

Similarly, Chigwamba (2013) proposes that banking procedures must be followed as prescribed by financial management statutes if mismanagement of public funds is to be equally minimized. This demands that banking be done daily and a summary of revenue collected be mastered to avert corrupt activities cropping up. Power needs to be devolved through delegation if the best of each individual is to be utilized. The mastery of the receipts may be done jointly by the bursar and the deputy education manager to ensure efficiency before the money is banked. Mobeg et al. (2012) are agreeable to the allocation of duties in this manner as it hinders fraud from occurring. When that has been attended to, all money received should be banked promptly (Carysforth and Neild, 2000). Routine banking of money collected ensures that no such money may be used before it is banked. Such a practice prevents thefts by burglary as no unbanked cash would be found in the safe. To further prevent theft by conversion which is usually committed by the banking officer, as a way of accountability, the bursar should insist on stamped duplicate receipts for recording in the banking register (SR, 2011). For checks and balances, all the cancelled receipts should not be detached from the receipt book and all those not cancelled should tally with the physical amount collected and banked (SR, 2011).

In the same vein, if reconciliation is done according to regularised accounting procedures, problems of misappropriation of school funds may be reduced (SR, 2011). The banked cash reflected on the bank statement should agree with the cash book balance if proper financial procedures have been followed. In this regard, reconciliation saves as an internal control as far as financial management is concerned. Carysforth and Neild (2000) support this procedure when they argue that at the end of each month all the accounts should be balanced so that any outstanding amounts may be accounted for. This therefore, implies that the management of financial information in this manner enables the education manager to detect abuse of public funds early before they get out of hand. Equally important are the end of year returns (Matimbe, 2014). These indicate the income and expenditure for the whole year. To enhance transparency in the utilisation of funds and revenue collection in the issuing year, the SDA must report the financial statement to the stakeholders so that they know what the money was used for and reasons for doing so (SI, 379 of 1998). After that the education manager must submit an audited financial report not later than the first term of the issuing year to the Provincial Education Director (SR, 2011). As part of hand-over and take-over process, the SDA books must be audited before the expiry of their term of office so that it is proved that there was no misappropriation of school funds (SI, 379 of 1998). Such practices if adhered to religiously would minimise the financial problems which are currently bedeviling Zimbabwean public schools.

\subsection{Strategies Meant to Reduce Financial Mismanagement}

Financial management entails following the accounting procedures stipulated in the APM of 1984. These if adhered to judiciously, risks in the management of school funds may be mitigated. Mobeg et al. (2012) argue that weak internal control mechanisms contribute to financial mismanagement; hence the education manager should have a school policy where the roles of each player are candidly delineated. There is need for members of the SFSC to be conversant with financial statutes through workshops or staff development courses. Most importantly, the education manager must be trained in the financial management discipline if proper accounting procedures are to be put in place. This kind of orientation makes those involved in financial management of public funds knowledgeable (Mobeg et al., 2012). When SFSC members and CAOs are informed in financial management, delegation of duties according to one's capabilities becomes easier (Porter and Norton, 2004). However, within the same scenario, Peter and Norton go further to suggest that duties need to be rotated to avoid problems which usually mushroom caused by one's overstaying at a particular post. In that manner, each member of the SFSC gains the experience of each post which goes with it. Such a practice reduces cases of members colluding with financiers or other members for the purpose of swindling school funds (Porter and Norton, 2004).

Furthermore, it is within the jurisdiction of the education manager to engage private auditors over and above those provided by the government funds permitting to check for compliance to the stipulated accounting procedures (Oakland, 2000). The re-examination of the accounting procedures actually through this kind of engagement may lead to system improvement unobtainable by other means. Regular audits by their nature help in identifying the problems early for rectification (Oakland). The education manager would be doing the system justice if $\mathrm{s}$ /he checks the accuracy of cash collection and disbursement methods employed by the bursar before certifying the correctness of such records (TI, 1992). Although monitoring for compliance is meant to detect fraudulent activities at their infancy, the correct accounting procedures need to be understood too, if one is to analyse, record, summarise, report and interpret financial transactions of an organisation appropriately.

\subsection{Methodology}

The study employed a qualitative approach on the ten participating schools. Qualitative studies thrive on lived experiences of participants (Creswell, 2014). The study was appropriately located within the interpretive research paradigm, which sees reality as subjective and built from the participant's views and interactions (Creswell). We utilised document analysis, participants as observers and a semi-structured interview (Creswell) in investigating the accounting procedures used by Zimbabwean public schools in the collection and disbursement of public funds 
since financial management has been decentralised. We reviewed documents on data entailing statutes on financial management, press reports on financial issues, records of minutes of the SFSC, school books of accounts, procurement procedures. We further scrutinised archived documents pertaining to financial management and policy documents as well. We also had access to privileged information on the phenomenon under investigation because one of us worked in one of the research sites (Denscombe, 2007). We were able to participate as observers so as to witness first hand and intimate details on the phenomenon as experienced by the informants by way of shadowing the bursar (Denscombe). Finally, an interview protocol derived from the content analysis of the documents observed and observation was conceived with the sole purpose of obtaining in-depth data which was valid and rich from ten purposefully sampled participants in each one of the following designations at each school: SDPs chairpersons, bursar, deputy education managers, and education managers. The interview protocol was preferred as it allowed researchers to probe further the responses of the participants, immediately verify the responses with those of other informants and it enhanced the response rate as well (Creswell, 2014). Data gathered using multiple sources facilitated the validation of data through triangulation (Denscombe, 2003). Researchers minimised bias which emanates from the 'Hawthorne effect' when an interview protocol is employed by making the researcher who was a workmate capture data while the co-researcher conducted them (Creswell). The generation of data commenced by coding qualitative data, classifying it according to emerging themes and converting it to quantitative data by way of content analysis (Creswell). Quantification of data was meant to illuminate the responses of the informants (Denscombe, 2007). In that way both quantitative and qualitative approaches were employed in the reporting of data gathered on accounting procedures practised in Zimbabwean public schools. Judging by the calibre of the participants and the multiplicity of data sources used, we were convinced that data gathered in this manner, was authentic, credible and representative of the financial accounting documents each school has in its custody for use, thus making it generalisable to other institutions of similar attributes (Creswell).

\subsection{Findings}

The data analysis process yielded four thematic areas, namely: accounting procedures employed by schools, utilisation of financial documents, problems encountered when accounting procedures are flouted and how risks associated with financial management may be reduced. In the section below we address the issues in that order.

Through Question 1 we sought to establish the accounting procedures each school employed in the collection of revenue and the results are depicted below.

Table-1. Accounting procedures employed to account for revenue in schools

\begin{tabular}{l|l|l}
$\mathbf{N}=\mathbf{4 0}$ & $\mathbf{f}$ & $\mathbf{\%}$ \\
\hline Attributes & 30 & 75 \\
\hline Procurement & 36 & 90 \\
\hline Payment vouchers & 40 & 100 \\
\hline Receipts & 40 & 100 \\
\hline Banking & 35 & 88 \\
\hline Reconciliation & 30 & 75 \\
\hline End of year returns & & \\
\hline
\end{tabular}

Table 1 reveals that all informants interviewed indicated that receipts $(100 \%)$ and banking $(100 \%)$ were used as accounting procedures. Some indicated that PVS $(90 \%)$, reconciliation $(88 \%)$, procurement $(75 \%)$ and end of term returns $(75 \%)$ were equally used. When we asked them to substantiate their claims through question 2 , their collective response was: "Receipting, banking and payment vouchers should be crucial if revenue is to be properly accounted for in schools." However, when we further scrutinised the financial documents we realised that although banking and receipting were done according to laid down procedures; some schools forgot to state the cancelled receipts in the master receipt books which raised our eye brows. Encouraging though within this scenario was that Deputy education managers diligently mastered collected funds daily and tallied figures with the physical amount (SR, 2011). On examination of PVS we discovered that these were not arranged according to serial numbers, invoices and quotations (Chigwamba, 2013) were not attached at all. On the contrary when, we confronted bursars whom we shadowed to establish why PVS were not used, they claimed that they were overwhelmed by their workload. Similarly, those who failed to reconcile the cash book with the bank statements claimed that they were not confident with figures, hence making it difficult for them to compile 'end of year returns'. This observation put their professional qualifications for the job open to suspect. Determined to ascertain which financial documents schools had in their custody and utilised appropriately (SR, 2011) we queried the following documents: Cash Book, Receipt Book, Banking Register, PVS and Procurement Minute Book through question 3, observed and the results are portrayed below.

Table-2. Utilisation of financial documents by schools

\begin{tabular}{|c|c|c|c|c|c|}
\hline Schools & Cash book & Receipts book & Banking register & Payments vouchers & Procurement minute book \\
\hline$\overline{\mathrm{A}}$ & $\sqrt{ }$ & $\sqrt{ }$ & $x$ & $x$ & $x$ \\
\hline B & $\sqrt{ }$ & $\sqrt{ }$ & $\sqrt{ }$ & $\sqrt{ }$ & $x$ \\
\hline $\mathrm{C}$ & $\sqrt{ }$ & $\sqrt{ }$ & $x$ & $\sqrt{ }$ & $x$ \\
\hline $\mathrm{D}$ & $\sqrt{ }$ & $\sqrt{ }$ & $\sqrt{ }$ & $x$ & $\sqrt{ }$ \\
\hline $\mathrm{E}$ & $\sqrt{ }$ & $\sqrt{ }$ & $\sqrt{ }$ & $x$ & $x$ \\
\hline $\mathrm{F}$ & $\sqrt{ }$ & $\sqrt{ }$ & $\sqrt{ }$ & $\sqrt{ }$ & $\sqrt{ }$ \\
\hline G & $\sqrt{ }$ & $\sqrt{ }$ & $\sqrt{ }$ & $x$ & $x$ \\
\hline $\mathrm{H}$ & $\sqrt{1}$ & $\sqrt{ }$ & $\sqrt{ }$ & $\sqrt{ }$ & $\sqrt{1}$ \\
\hline I & $\sqrt{1}$ & $\sqrt{ }$ & $\sqrt{ }$ & $\sqrt{ }$ & $\sqrt{ }$ \\
\hline $\mathrm{J}$ & $\sqrt{ }$ & $\sqrt{ }$ & $x$ & $x$ & $x$ \\
\hline
\end{tabular}


Table 2 above reveals that for the disbursement and collection of public funds, most Zimbabwean schools always used the 'Cash' and 'Receipt book' for this purpose. When we further examined these school records we also discovered that only seven of the schools investigated always 'registered' monies collected and banked it (Chigwamba, 2013; Hill, 2015). On further probing the bursars who obliged by the banking procedures, all indicated that any member of the SFSC could be sent to the bank with the collected revenue. Such a person takes deposit ships together with remittance to the bank and a triplicate copy of deposit slips is returned by the bank teller dully endorsed (Chigwamba; Hill). Interesting to note within this scenario was that, only five schools seemed to be employing the use of 'PVS' for the approval of payments and four of these were not forgetting to minute their priorities and approval of purchases as directed by the SFSC in the 'Procurement Minute Book'. Based on these findings we concluded that there was a discrepancy in as far as the utilisation of books of accounts in Zimbabwean public schools is concerned. However, the presence of some schools who do not use the banking register, PVS and Procurement Minute Book for whatever reasons was a cause of concern to us, more so, with the rampant misappropriation of public funds in Zimbabwean schools as alluded to earlier on.

Question 4 was meant to establish problems which may be experienced by education managers in schools if proper accounting procedures are ignored, Table 3 below displays the predicaments.

Table-3. Problems associated with incorrect accounting procedures

\begin{tabular}{l|l|l}
$\mathbf{N}=\mathbf{4 0}$ & $\mathbf{f}$ & $\mathbf{\%}$ \\
\hline Attribute & 40 & 100 \\
\hline Frauds & 38 & 95 \\
\hline Misappropriation of funds & 40 & 100 \\
\hline Under banking / overbanking & & \\
\hline
\end{tabular}

Through Table 3 we observed that fraudulent activities (100\%) were prevalent in schools in the same way under/over banking was Ncube (2016). Similarly, we also discovered that cases of misappropriation of funds (95\%) were equally prevalent in schools investigated. When we probed the informants further, they could not confirm whether it was by design or accident. However, they all were in consonant with one sentiment expressed by one of the participants through question 5 which was a follow up of the above revelations who concurred that education managers usually fall prey to such social evils despite them being equipped with statutes which regulate financial management in schools because: "they do not follow procurement or banking procedures properly for they usually end up in jail due to mismanagement of public funds." This observation in our informed view, served to confirm the absence of such crucial documents in some Zimbabwean schools investigated: 'Banking Register', 'PVS' and the 'Procurement Minute Book' (see Table 2).

With the prevalence of gross incorrect accounting procedures at the back of our minds, informants (excluding deputy education managers) were interrogated on how the risks of financial management could either be minimised or eliminated through question 6 and the results are shown below.

Table-4. How the risk of financial mismanagement can be reduced in schools?

\begin{tabular}{l|l|l}
$\mathbf{N}=\mathbf{3 0}$ & $\mathbf{f}$ & $\mathbf{\%}$ \\
\hline Attributes & 30 & 100 \\
\hline Training / workshops & 30 & 100 \\
\hline Delegation of duties & 25 & 83 \\
\hline Induction of SDA/ SDC & 30 & 100 \\
\hline Auditing & 28 & 93 \\
\hline Internal controls &
\end{tabular}

Table 4 reveals that informants seem to agree that cases of maladministration of public funds may be reduced if education managers who are $\mathrm{CAO}$ in schools are either trained or work-shopped (100\%) together with the SDA Chairpersons (83\%) in financial management statutes and members of the SFSC as well (Porter and Norton, 2004). The significance of this observation to this study cannot be over-emphasised, more so, that further interrogations revealed that such workshops were last manned in 2013. Regardless of that anomaly, participants also indicated that financial management duties should be a collective responsibility (Mobeg et al., 2012) of the SFSC by way of delegation (100\%). Most importantly, they also suggested that school books of accounts should be audited (100\%) as regulated by the statutes for checks and balances (TI, 1992). Little wonder that one of the informants when probed further remarked that funds permitting, education managers would be acting within their jurisdiction by hiring private auditors when misappropriation of funds is suspected to audit school books of accounts (Oakland, 2000). Over and above that, they also intimated that internal controls (93\%) through the SFSC should be put in place so as to check for both compliance and non-compliance of accounting procedures periodically before the financial ills escalate (Carysforth and Neild, 2000; Mobeg et al., 2012). In that way, we were convinced that misappropriation of funds would probably be curbed as financial literacy would probably prevail, although is not always the case.

\subsection{Discussion}

Generally, the majority of Zimbabwean primary schools seem to adhere to the stipulated accounting procedures as observed by the number of schools which seem to be adhering to these procedures religiously (SR, 2011).Given this scenario, we felt that the few who seemed to be ignoring these procedures for whatever reasons have no internal controls in place to monitor compliance (Carysforth and Neild, 2000; Mobeg et al., 2012). As researchers we conjectured that in public schools were such ill-practices prevailed either the education manager was devoid of financial management knowledge or the bursars lacked supervision because a scrutiny of their qualifications revealed that they were all qualified for the job. This revelation baffled us and on reflection we concluded that the flouting of these accounting procedures was deliberate and reasons advanced by the incumbents 
such as mathematical phobia and being overwhelmed by the work load were lame. Based on this empirical evidence revealed by this study, we suggest that external supervision of public funds through audits be increased if misappropriation of funds which we suspect to be rampant in some of the schools investigated is to be curbed.

Such audits must entail checking the existence of a robust and viable SFSC whose functions are substantiated by authentic minutes duly signed by the $\mathrm{CAO}$ and the Bursar which may serve as evidence by schools in complying with the requirements of the financial management statutes (SI, 379 of 1998; SR, 2011). It is this body if formally constituted and fully operationally, superintends the internal controls of the school books of accounts and the accounting procedures in place in terms of compliance and non-compliance if the financial malaise rocking such institutions nowadays is to be detected at its infancy and rectified. The feasibility of such a thrust in our informed view would be determined by the wealth of knowledge and skills the CAO and members of SFSC (SDA Chairpersons/vice included) have at an operational level.

For these accounting officers to acquire appropriate knowledge and skills in financial management, we strongly believe that they be work-shopped on a regular basis so as to arm them with the relevant and updated technical knowhow they need to discharge their duties effectively and efficiently. Such empowerment would enable the CAO to delegate duties on a rotational basis as one way of trying to minimise fraudulent activities which crop up when individuals hold assigned portfolios permanently within the SFSC framework (Porter and Norton, 2004; Mobeg et al., 2012). However, SDA members whose term of office is limited to a year (SI, 379 of 1998) would need more regularised sessions if they are to be conversant with the statutes and financial management practices, more so, that most of them come from different socio-economic and educational backgrounds. When such measures are put in place in the public schools which were found flouting the accounting procedures at willy-nilly, we are convinced as researchers that corrupt tendencies which are usually associated with ill-practices in procurement of educational resources and awarding of tenders may either be minimised or done away with.

Zimbabwean public schools through the audit section department located at the PED offices are usually audited at least once a year (SR, 2011). This practice as researchers, we felt that it was inadequate. We believe that such a daunting task cannot be left in the hands of the government alone, as its financial resources are already overstretched by the phenomenal expansion of the education system due to the 'education for all' policy enunciated at independence $(\mathrm{GoZ}, 1987)$. Consequently cases of some schools going for three years or more without an external audit are common. Would-be fraudsters seem to have capitalised on this laxity of the system and the ignorance of some SFSC and SDA members to embezzle school funds. To curb this rot which has infested most public institutions of late as revealed by this empirical research, there is need for schools to engage private auditors, resources permitting to check for compliance and for the detection of fraudulent activities on time. Situations such as those observed through this study where school accounting officers flout basic accounting procedures for whatever reasons must not be tolerated as this is the genesis of fraudulent activities which need to be nipped in the bud by having robust internal controls. While external auditing may be taxing, employing knowledgeable and skilled education managers and bursars in financial management principles would minimise the rot. In that view, cases of bursars claiming that they could not undertake certain accounting procedures because of their mathematical phobia as observed earlier on would be a thing of the past.

\subsection{Conclusions}

Participants' responses and observations experienced on the ground have made us conclude that the mediocrity in the manner in which accounting procedures are adhered to by some Zimbabwean primary schools and laxity of the monitoring system needs regular internal and external auditing resources permitting to curtail the misappropriation of public funds which we believe is rampant as revealed by this study. Attempts should be made at all cost to employ knowledgeable personnel in financial management or workshop those on the ground periodically if the public is to have confidence in the financial management of public funds prevailing in schools. Most importantly, education managers as CAO must put proper financial management structures in place which would enable them to detect fraud associated with white-collar crime at its infancy to minimise this rot which has seen competent and hardworking officers being caged due to the laxness of the system.

\section{References}

Bansal, G.S., 2011. Basic accounting: Payment voucher. Retrieved from www.letslearnaccounting.

Carysforth, C. and M. Neild, 2000. Business studies. Oxford: Heinmann.

Chigwamba, C., 2013. The financial management training manual for the non -financial education managers, financial administration, human resources and discipline. Harare: Government Printers.

Chiri, M., 2015. Looting spree in Zimbabwe schools. Financial Gazette: 4.

Creswell, J.W., 2014. Research design: Qualitative, quantitative and mixed methods approach. 4th Edn., London: Sage.

Denscombe, M., 2003. The good research guide for small-scale social research projects. 2nd Edn., England: Open University Press.

Denscombe, M., 2007. The good research guide for small-scale social research projects. 3rd Edn., England: Open University Press.

GoZ, 1987. The education act; chapter 25:04. Harare: Government Printers.

Harare Bureau, 2016. New rules for school levies. The Sunday News: 2.

Hill, R., 2015. What is bank reconciliation? Retrieved from www.linkeddin.com/pulse/reconcile-co.

Kent, J., 2015. Bank reconciliation statements: Accountibility and profitability. Retrieved from www.iiste.org/journals/index.

Masasi, M., 1997. Accounts. Harare: College Press.

Matimbe, R.T., 2014. Master of education in educational management: Financial management in education. Harare: ZOU.

Mobeg, F.O., B.A. Odigi and E.M. Simatwa, 2012. Factors contributing to financial mismanagement and misappropriation in public secondary schools. Maseno: Eregi Teachers' Training College.

Ncube, L., 2016. Schools to employ full time accountants. The Chronicle: 2.

Oakland, J.S., 2000. Total organisation excellence. London: Butterworth.

Porter, G.A. and C.L. Norton, 2004. Financial accounting. New York: Thomson Learning.

Szilagyi, A.D., 1981. Management and perfomance. London: Scott, Foreman and Company.

\section{Bibliography}

GoZ, 1998. Statutory instrument 379: Education (School Development Association) (Government Schools) regulations. Harare: Government Printers. 
GoZ, 1992. Treasury instructions. Harare: Government Printers.

GoZ, 1991. The education amended act; chapter 25:04. Harare: Government Printers.

GoZ, 1984. Accounting procedures manual. Harare: Government Printers.

GoZ, 2009. The public finance management act. Harare: Government Printers

GoZ, 2011. The public finance management act. Harare: Government Printers.

GoZ, 2011. School regulations. Harare: Government Printers.

Citation | V.C. Ngwenya; J. Maushe (2017). Accounting Procedures within a Decentralised Zimbabwean Financial Management School System. Journal of Banking and Financial Dynamics, 1: 21-28. History:

Received: 28 January 2017

Revised: 25 April 2017

Accepted: 8 May 2017

Published: 15 May 2017

Licensed: This work is licensed under a Creative Commons

Attribution 3.0 License (c))

Publisher: Eastern Centre of Science and Education
Acknowledgement: Both authors contributed to the conception and design of the study.

Funding: This study received no specific financial support.

Competing Interests: The authors declare that they have no conflict of Competing

Transparency: The authors confirm that the manuscript is an honest, accurate, and transparent account of the study was reported; that no vital features of the study have been omitted; and that any discrepancies from the study as planned have been explained.

Ethical: This study follows all ethical practices during writing.

Eastern Centre of Science and Education is not responsible or answerable for any loss, damage or liability, etc. caused in relation to/arising out of the use of the content. Any queries should be directed to the corresponding author of the article. 